\begin{tabular}{|l|l|l|}
\hline \multicolumn{2}{|c|}{ PublisherInfo } \\
\hline \hline PublisherName & $:$ & BioMed Central \\
\hline \hline PublisherLocation & $:$ & London \\
\hline \hline PublisherImprintName & $:$ & BioMed Central \\
\hline \hline
\end{tabular}

\title{
Transcription factor moonlights
}

\begin{tabular}{|l|l|l||}
\hline \multicolumn{2}{|c|}{ ArticleInfo } \\
\hline \hline ArticleID & $:$ & 5089 \\
\hline \hline ArticleDOI & $:$ & $10.1186 /$ gb-spotlight-20050527-01 \\
\hline \hline ArticleCitationID & $:$ & spotlight-20050527-01 \\
\hline \hline ArticleSequenceNumber & $:$ & 65 \\
\hline \hline ArticleCategory & $:$ & Research news \\
\hline ArticleFirstPage & $:$ & 1 \\
\hline \hline ArticleLastPage & $:$ & 4 \\
\hline \hline & & RegistrationDate : 2005-5-27 \\
\hline ArticleHistory & $:$ & OnlineDate \\
\hline \hline ArticleCopyright & $:$ & BioMed Central Ltd2005-5-27 \\
\hline \hline ArticleGrants & $:$ & \\
\hline \hline ArticleContext & $:$ & 130596611 \\
\hline \hline
\end{tabular}


Graciela Flores

Email: graciela_flores@nasw.org

Activating transcription factor 2 (ATF2), known for its function in gene regulation, has another totally unrelated role in responding to DNA damage, US researchers report in Molecular Cell this week.

"Here, we show for the first time that a transcription factor has a function in the DNA damage response that is completely independent of its transcriptional activity," Ze'ev Ronai, of the Burnham Institute in La Jolla, Calif., told The Scientist.

For its transcriptional regulatory roles, ATF2 is activated by phosphorylation via the JNK/p38 pathway. The group found alternate phosphorylation sites at serines 490 and 498 that are generally recognized by the kinase ataxia telangiectasia mutated (ATM), which is implicated in double-strand break (DSB) repair. They found ATF2 phosphorylated at those serines localizing at irradiation-induced DSB repair foci. When they inhibited JNK/p38 or disrupted transcriptional regulatory activity of ATF2, the protein continued to show up at these DSBs and maintained proper S-phase checkpoint, indicating that its role in DNA damage response is uncoupled from its transcriptional activities.

Using antibodies to ATF2 and RNA interference, Ronai and colleagues studied ATF2 in cultured mammalian cells subjected to ionizing radiation and in ATF2 mutant mice. The results showed that ATF2 is phosphorylated by ATM and that ATF2 plays an important role in the double-strand break repair process.

In the last decade, evidence supporting the idea that certain proteins - so-called moonlighting proteins- can perform multiple jobs has mounted. The novelty of this paper is that it demonstrates that the two functions of ATF2 are uncoupled.

"ATF2 doesn't need its transcriptional activity to participate in the DNA damage response," said Dan Mercolaat the Sidney Kimmel Cancer Center, San Diego, Calif., who was not involved in the study. "The authors show that a nontranscriptionally active form appears to be aggregating at DNA damage sites. The studies are very beautiful, and the data are very convincing."

William Bonnerat the National Cancer Institute's Center for Cancer Research, who did not participate in the research, said the paper was an interesting development, but he would like to see further experiments. "A protein, originally identified as a transcription factor, and that behaves as a transcription factor, has now been involved in the DNA damage response," said Bonner. "Whether there is some linkage between these two functions remains to be clarified."

It also remains to be seen how the transcription factor's two functions are balanced. Both functions depend upon phosphorylation, which can occur through the JNK/p38 pathway or through the newly linked ATM pathway. "A normally growing cell, subjected to cytokine stimulation or to UV radiation, activates ATF2's transcriptional machinery through the JNK/p38 pathway," explained Ronai. "But when the cell is subjected to ionizing radiation or when it detects a double-strand break, the ATM pathway is activated instead, and ATF2 performs a completely different role: it promotes cell cycle arrest and DNA synthesis, and allows DNA repair to take place." 
Ronai said that ATF2 normally performs only one of its two functions, but that in certain unique situations, such as high doses of radiation, or in cancer, both pathways are upregulated. "At that point, we expect to have an imbalance of ATF2's two functions, a decrease in its DNA repair activity or in its transcriptional activity. We know that, for example, in melanoma, there is upregulation of both ATM and JNK/p38. We are now trying to determine how ATF2 can balance its dual roles."

Ronai and his colleagues have devoted substantial efforts to developing compounds capable of inhibiting ATF2 activity, particularly in melanoma. "We've documented that ATF2 contributes to the development and the resistance of melanoma to treatments, and we've developed a peptide that can inhibit ATF2's activity, and reduce melanoma growth significantly. But until now, we have attributed the ability of the peptide to attenuate melanoma growth to the transcriptional activity of ATF2. In light of our new results, we will now evaluate the possibility that this peptide may also be capable of altering the DNA damage contribution of ATF2," said Ronai.

The team now plans to focus on how AFT2 contributes to the DNA damage response, dissecting the mechanism at the level of chromatin organization.

\section{References}

1. A. Bhoumik et al.,"ATM-dependent phosphorylation of ATF2 is required for the DNA damage response," Mol Cell, May 27, 2005., [http://www.molecule.org/]

2. Ze'ev Ronai, [http://www.burnham.org/FacultyAndResearch/Faculty/ze'ev_ronai_bio.asp]

3. K.Y. Kreeger, "Signal transduction," The Scientist, April 28, 1997., [http://www.the-scientist.com/ $1997 / 4 / 28 / 12 / 2]$

4. L.B. Schultz, "The quest for protectors of genomic stability," The Scientist, May 19, 2003., [http://www.the-scientist.com/2003/5/19/29/1]

5. J. Lucentini, "Enzymatic alter-egos unmasked," The Scientist, October 6, 2003., [http://www.thescientist.com/2003/10/6/23/1]

6. Dan Mercola, [http://www.skcc.org/mercola.html]

7. William M. Bonner, [http://ccr.cancer.gov/staff/staff.asp?profileid=5814]

8. L.B. Schultz, "Aberrant signaling," The Scientist, September 22, 2003., [http://www.thescientist.com/2003/9/22/S10/1] 
(c) 2009-2013. SPi Global, Chennai, India. All rights reserved. 